\title{
PROFIL ASAM LEMAK MINYAK TEMPE BUSUK
}

\author{
M. H. Rachmawati, H. Soetjipto*, dan A. I G. N. Kristijanto \\ Program Studi Kimia, Fakultas Sains dan Matematika, Universitas Kristen Satya Wacana, \\ Jln. Diponegoro No. 52 - 60, Salatiga, 50711, Indonesia \\ "Email: hartati.sucipto@staff.uksw.edu
}

\begin{abstract}
ABSTRAK
Tempe busuk merupakan produk pangan yang dimanfaatkan oleh masyarakat Indonesia sebagai penyedap masakan. Sampai sejauh ini, tempe busuk kurang mendapat perhatian dibanding dengan tempe segar dan penelitian mengenai tempe busuk belum banyak dilakukan. Tujuan penelitian adalah mengidentifikasi profil asam lemak minyak tempe busuk hasil fermentasi hari kelima sebelum dan sesudah pemurnian dengan menggunakan KG - SM (Kromatografi Gas Spektroskopi Massa). Ekstraksi minyak tempe busuk hasil fermentasi hari kelima dilakukan dengan metode sokletasi menggunakan pelarut $n$ - heksana, kemudian minyak dimurnikan dan profil asam lemak minyak tempe busuk dianalisis dengan menggunakan $\mathrm{KG}-\mathrm{SM}$. Proses pemurnian dengan menggunakan $\mathrm{H}_{3} \mathrm{PO}_{4} \quad 0,2 \%$ dan $\mathrm{NaOH}$ $0,1 \mathrm{~N}$. Hasil penelitian menunjukkan ada perbedaan jumlah asam lemak penyusun minyak tempe busuk hari kelima sebelum dan sesudah pemurnian yaitu minyak tempe busuk sebelum pemurnian mengandung delapan senyawa, sebaliknya minyak tempe busuk sesudah pemurnian hanya tersusun oleh lima senyawa. Delapan senyawa penyusun minyak tempe busuk sebelum pemurnian antara lain $n$ - Hexadecanoic acid/ asam palmitat $(13,33 \%)$, 9, 12 Octadecadienoic acid (Z, Z)-/ asam linoleat (77,57\%), Octadecanoic acid/ asam stearat (6,15\%), dan lima komponen kimia lain yang memiliki persentase area $<3 \%$. Sebaliknya senyawa - senyawa penyusun minyak tempe busuk sesudah pemurnian terdiri dari $n$-Hexadecanoic acid/ asam palmitat (12,38\%), 9, 12 - Octadecadienoic acid (Z, Z)-/ asam linoleat (80,27\%), Octadecanoic acid/ asam stearat (5,84\%), dan senyawa lain yang jumlahnya <3\%.
\end{abstract}

Kata Kunci: asam lemak, fermentasi, minyak tempe busuk, pemurnian

\begin{abstract}
Overripe tempe is a food product that used by peoples in Indonesia as a food seasoning. So far, overripe tempe received less attention than fresh tempe and research of overripe tempe is rarely done. The objective of the study is to identify the fatty acid profile of fifth day fermentation overripe tempe oil before and after purification using GC - MS (Gas Chromatography - Mass Spectrometry). In this study, overripe tempe oil of fifth day fermentation was extracted with soxhletation method using $n$-hexane solvent, then it was purified, and the fatty acid profiles of overripe tempe oil were analyzed by $\mathrm{GC}-\mathrm{MS}$. The purification processes are done by using $\mathrm{H}_{3} \mathrm{PO}_{4} 0,2 \%$ and $\mathrm{NaOH} 0,1 \mathrm{~N}$. The result of the study showed that there is a difference of fatty acids amount in the tempe oil of fifth day fermentation before and after purification, which is overripe tempe oil before purification consisted eight compunds, in the contrary, the overripe tempe is oil only consisted of five compunds after purification. Eight compounds of overripe tempe oil before purification are 13,33\% $\mathrm{n}$ - Hexadecanoic acid/ palmitic acid, 77,57\% 9, 12 - Octadecadienoic acid (Z, Z)-/ linoleic acid, 6,15\% Octadecanoic acid/ stearic acid, and the five chemical components have percentage of areas <3\%, respectively. Whereas the overripe tempe oil composition coumpunds after purification are $12,38 \% \mathrm{n}-\mathrm{Hexadecanoic}$ acid/ palmitic acid, 80,27\% 9, 12 - Octadecadienoic acid (Z, Z)-/ linoleic acid, 5,84\% Octadecanoic acid/ stearic acid, and other compounds that have percentage of areas $<3 \%$, respectively.
\end{abstract}

Keywords: fatty acid, fermentation, overripe tempe oil, purification

\section{PENDAHULUAN}

Tempe merupakan produk makanan fermentasi berbahan dasar kedelai yang sangat populer di Indonesia. Kandungan gizi dari tempe yaitu air $64 \%$, protein $18,3 \%$, lemak $4 \%$, dan karbohidrat 12,7\% (Triwibowo, 2011). Tempe yang sering dikonsumsi oleh masyarakat adalah tempe hasil fermentasi hari kedua (Devi et al., 2017). Tempe terfermentasi lanjut dikenal oleh masyarakat dengan nama tempe busuk. Tempe busuk berperan penting dalam meningkatkan citarasa dari masakan tradisional Jawa (Gunawan et al., 2012). Beberapa masakan Jawa yang 
menggunakan tempe busuk sebagai bahan penyedap seperti sayur tumpang, lodeh, gudeg, bothok, dan lain-lain.

Fermentasi lanjut pada tempe akan menyebabkan terpecahnya komponen - komponen kompleks seperti lemak menjadi asam lemak. Menurut Deliani (2008) lama fermentasi tempe yang semakin meningkat juga akan meningkatkan jenis asam lemak yang dihasilkan dari proses pertumbuhan bakteri - bakteri selama proses fermentasi.

Setiawan et al. (2017) menyatakan bahwa rendemen minyak tempe optimal diperoleh pada fermentasi hari ketujuh yaitu sebesar 13,18 \pm $0,44 \%$, minyak tersebut tersusun oleh lima jenis asam lemak yang didominasi oleh metil linoleat. Asam linoleat merupakan asam lemak golongan omega 6. Sebaliknya menurut Rachmawati et al. (2018) melaporkan bahwa minyak tempe busuk optimal sebesar $10,61 \pm 0,66 \%$ dihasilkan pada tempe hasil fermentasi selama 5 hari.

Minyak kasar hasil ekstraksi umumnya masih mengandung zat pengotor seperti fosfolipid, asam lemak bebas, pigmen, dan getah. Zat pengotor tersebut berpengaruh terhadap kualitas minyak seperti aroma, masa simpan, maupun kejernihan minyak (Verleyen et al., 2002). Upaya untuk meningkatkan kualitas dari minyak adalah dengan melakukan pemurnian minyak (degumming dan netralisasi).

Sampai sejauh ini, tempe busuk kurang mendapat perhatian dibanding dengan tempe segar. Penelitian tentang tempe busuk juga belum banyak dilakukan. Sehingga dilakukan penelitian mengenai identifikasi profil asam lemak penyusun minyak tempe busuk hasil fermentasi hari kelima sebelum dan sesudah pemurnian dengan menggunakan KG - SM.

\section{Alat dan Bahan}

\section{METODE PENELITAN}

Alat yang digunakan antara lain neraca analitis dengan ketelitian 0,0001 g (OHAUS PA214, USA), neraca analitis dengan ketelitian 0,01 g (OHAUS TAJ602, USA), soklet, grinder, penangas air (Memmert WNB 14, Jerman), rotary evaporator (BUCHI R-114, Swiss), drying cabinet, stirrer, hot plate, corong pisah, swing type centrifuge (Tomy Seiko C-40N, Jepang), peralatan gelas, dan KG - SM (Perkin Elmer).

Bahan yang digunakan dalam penelitian adalah sampel tempe yang diperoleh dari pabrik tempe kedelai " $X$ " di Bugel, Salatiga, Jawa Tengah. Sedangkan bahan kimiawi yang digunakan untuk ekstraksi dan pemurnian adalah $n$ - heksana (p.a), $\mathrm{H}_{3} \mathrm{PO}_{4}, \mathrm{NaOH}$, dan akuades. Semua bahan kimiawi yang digunakan produk Merck, Jerman.

\section{Preparasi Sampel Serbuk Tempe}

Sampel tempe yang digunakan diambil dari waktu fermentasi selama 5 hari. Sampel dipotong tipis - tipis lalu dikeringkan dalam drying cabinet pada suhu $50^{\circ} \mathrm{C}$ selama 2 hari. Sampel yang sudah kering dihaluskan dengan grinder, disimpan dalam wadah kering yang diberi silica gel dan serbuk tempe siap digunakan untuk analisis lebih lanjut.

\section{Ekstraksi Minyak Tempe (Albertina et al., 2015)}

Sebanyak $50 \mathrm{~g}$ serbuk tempe diekstraksi dengan $300 \mathrm{~mL}$ pelarut $n$ - heksana pada suhu $80^{\circ} \mathrm{C}$ selama 6 jam. Hasil ekstraksi kemudian dipekatkan dengan rotary evaporator pada suhu $50-60^{\circ} \mathrm{C}$ sehingga diperoleh minyak tempe yang pekat. Minyak hasil ekstraksi dipindahkan ke dalam botol sampel yang telah ditimbang, kemudian dikukus untuk menghilangkan sisa pelarut yang masih terperangkap didalamnya. Selanjutnya hasil minyak disimpan dalam kulkas pada suhu $15^{\circ} \mathrm{C}$ sampai siap untuk analisis lebih lanjut. Rendemen minyak dihitung dengan Persamaan. (1).

$\%$ Rendemen minyak kasar $=\frac{\text { massaminyak }}{\text { massasampel }} \times 100 \%$

\section{Pemurnian Minyak (Keraba et al., 2017)}

Proses pemurnian minyak diawali dengan proses degumming. Minyak hasil ekstraksi ditimbang $5 \mathrm{~g}$. Minyak dipanaskan hingga suhu mencapai $70-75^{\circ} \mathrm{C}$ dan ditambahkan $\mathrm{H}_{3} \mathrm{PO}_{4} 20 \%$ sebanyak $0,2 \%$ (v/b) dari bobot minyak. Dilakukan pengadukan selama 10 menit pada suhu $70-75^{\circ} \mathrm{C}$. Minyak dimasukkan ke dalam corong pemisah untuk dicuci dengan akuades suhu $60^{\circ} \mathrm{C}$ hingga air buangan memiliki $\mathrm{pH}$ netral. Kemudian dilakukan sentrifugasi kecepatan 90 rpm selama 15 menit.

Tahap selanjutnya dilakukan proses netralisasi menggunakan $\mathrm{NaOH}$. Minyak hasil sentrifugasi dipanaskan pada suhu $70-75^{\circ} \mathrm{C}$ dan ditambahkan larutan $\mathrm{NaOH}$ konsentrasi $0,1 \mathrm{~N}$. Minyak diaduk selama 15 menit. Minyak dimasukkan kedalam corong pemisah untuk dicuci dengan akuades suhu $60^{\circ} \mathrm{C}$ hingga air buangan memiliki $\mathrm{pH}$ netral. Selanjutnya dilakukan sentrifugasi kecepatan 90 rpm selama 15 menit. 


\section{Analisis Profil Asam Lemak Minyak Tempe Busuk}

Profil asam lemak penyusun minyak tempe busuk dianalisis dengan menggunakan KG - SM tipe Perkin Elmer di Laboratorium Analis UNNES, Semarang. Jenis kolom yaitu AGILENT\%W DB-1 dengan panjang 30 meter dan suhu $50^{\circ} \mathrm{C}$. Suhu injeksi $250^{\circ} \mathrm{C}$ pada tekanan $16,5 \mathrm{kPa}$ dengan kecepatan linier $0,0551 \mathrm{~cm} /$ detik. ID $0,25 \mathrm{~mm}$ dengan gas pembawa Helium dan pengionan EI+.

\section{HASIL DAN PEMBAHASAN}

Identifikasi asam lemak penyusun minyak tempe busuk hasil fermentasi hari kelima dilakukan dengan menggunakan sampel sebelum dan sesudah pemurnian. Hasil analisis minyak tempe busuk hari kelima sebelum pemurnian disajikan dalam Gambar 1.

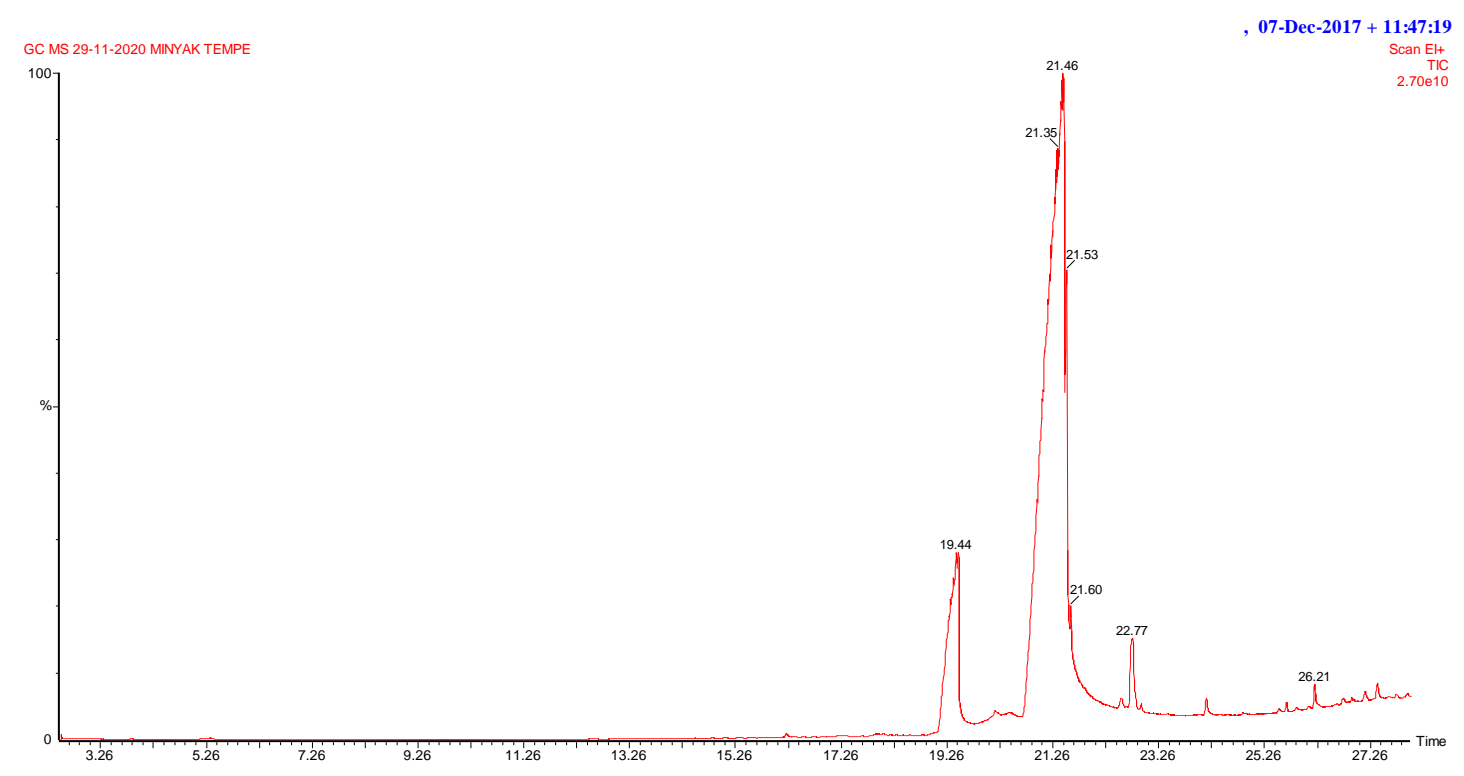

Gambar 1. Kromatogram GC - MS Minyak Tempe Busuk H - 5 Sebelum Pemurnian

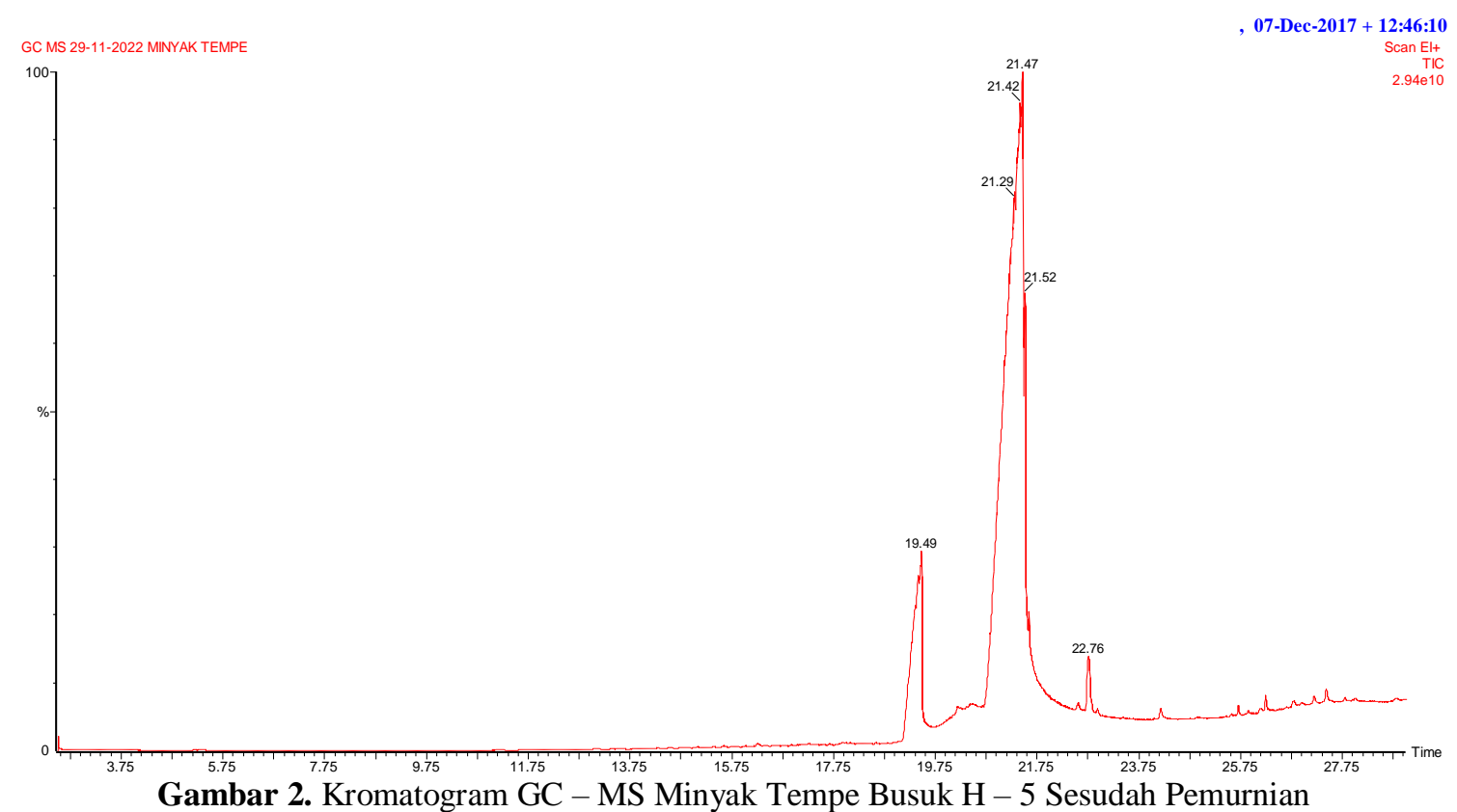


Profil Asam Lemak Minyak Tempe Busuk M. H. Rachmawati, H. Soetjipto, dan A. I G.N. Kristijanto

Tabel 1. Profil Asam Lemak Penyusun Minyak Tempe H - 5 Sebelum dan Sesudah Pemurnian

\begin{tabular}{|c|c|c|c|c|c|c|}
\hline \multirow[b]{2}{*}{ NP } & \multicolumn{3}{|c|}{ Sebelum Pemurnian } & \multicolumn{3}{|c|}{ Sesudah Pemurnian } \\
\hline & $\begin{array}{c}\mathrm{W}_{\mathrm{R}} \\
\text { (menit) }\end{array}$ & Area $(\%)$ & Komponen Kimia & $\begin{array}{c}\mathrm{W}_{\mathrm{R}} \\
\text { (menit) }\end{array}$ & Area $(\%)$ & Komponen Kimia \\
\hline 1 & 19,44 & 13,3311 & $\begin{array}{c}n-\text { Hexadecanoic acid, methyl ester, } \\
\text { (Asam Palmitat) }\end{array}$ & 19,485 & 12,3846 & $\begin{array}{c}\text { n-Hexadecanoic acid, methyl ester, } \\
\text { (Asam Palmitat) }\end{array}$ \\
\hline 2 & 21,456 & 77,5693 & $\begin{array}{l}\text { 9, } 12 \text { - Octadecadienoic acid }(Z, Z)- \\
\text { methyl ester, (Asam Linoleat) }\end{array}$ & 21,291 & 0,0787 & $\begin{array}{l}\text { 9, } 12 \text { - Octadecadienoic acid }(Z, Z)-\text {, } \\
\text { methyl ester, (Asam Linoleat) }\end{array}$ \\
\hline 3 & 21,526 & 6,1468 & $\begin{array}{c}\text { Octadecanoid acid, methyl ester, } \\
\text { (Asam Stearat) }\end{array}$ & 21,466 & 80,2734 & $\begin{array}{l}\text { 9, } 12 \text { - Octadecadienoic acid }(Z, Z)-, \\
\text { methyl ester, (Asam Linoleat) }\end{array}$ \\
\hline 4 & 22,772 & 1,8585 & $\begin{array}{c}9 \text { - Octadecenamide, (Z)-, methyl } \\
\text { ester }\end{array}$ & 21,516 & 5,8390 & $\begin{array}{c}\text { Octadecanoid acid, methyl ester, (Asam } \\
\text { Stearat) }\end{array}$ \\
\hline 5 & 24,167 & 0,2957 & Oleic acid, methyl ester & 22,757 & 1,4243 & 17 - Octadecynoic acid, methyl ester \\
\hline 6 & 26,208 & 0,3771 & $\begin{array}{l}\text { Cholestane - 3, 7, 12, } 25 \text { - tetrol, } \\
\text { tetraacetate, }(3 \alpha, 5 \beta, 7 \alpha, 12 \alpha) \text { - }\end{array}$ & & & \\
\hline 7 & 27,158 & 0,1926 & $\begin{array}{c}\text { Dasycarpidan }-1 \text { - methanol, acetate } \\
(\text { ester })\end{array}$ & & & \\
\hline 8 & 27,393 & 0,2289 & $\begin{array}{c}\text { 6, } 7 \text { - Epoxypregn - } 4 \text { - ene }-9,11 \\
18-\text { triol }-3,20 \text { - dione, } 11,18- \\
\text { diacetate }\end{array}$ & & & \\
\hline
\end{tabular}

Keterangan : NP = Nomor Puncak ; WR = Waktu Retensi

Hasil analisis kromatografi gas spektroskopi massa minyak tempe busuk hari kelima sebelum pemurnian diperoleh delapan senyawa asam lemak dengan puncak tertinggi yaitu puncak nomor 2. Kromatogram hasil analisis minyak tempe busuk hari kelima sesudah pemurnian ditampilkan pada Gambar 2.

Berdasarkan Gambar 2 terlihat bahwa minyak tempe busuk hari kelima sesudah pemurnian mengandung lima senyawa. Hal ini ditunjukkan dengan munculnya lima puncak pada kromatogram. Senyawa yang paling dominan muncul dengan puncak yang paling tinggi yaitu puncak nomor 3. Perbandingan antara senyawa asam lemak penyusun minyak tempe busuk sebelum dan sesudah pemurnian disajikan pada Tabel 1.

Berdasarkan Tabel 1 terlihat bahwa terdapat perbedaan jumlah asam lemak penyusun minyak tempe busuk hari kelima sebelum dan sesudah pemurnian yaitu minyak tempe busuk sebelum pemurnian mengandung delapan senyawa, sebaliknya minyak tempe busuk sesudah pemurnian hanya tersusun oleh lima senyawa. Nampaknya proses pemurnian dapat menghilangkan senyawa - senyawa pengotor dalam minyak seperti getah, asam lemak bebas, senyawa yang mengandung nitrogen, fosfolipid, pigmen dan senyawa - senyawa kompleks lainnya (Ketaren, 1986).

Minyak tempe busuk hari kelima sebelum dan sesudah pemurnian mengandung tiga asam lemak yang sama. Asam lemak tersebut antara lain $n$ - Hexadecanoic acidl asam palmitat, 9, 12 Octadecadienoic acid $(Z, Z)$ - / asam linoleat, dan Octadecanoid acidl asam stearat dengan masing masing nilai persentase area tercantum pada Tabel 1. Diantara ketiga asam lemak tersebut yang paling dominan adalah asam linoleat $(77,57 \%$ 80,27\%). Asam linoleat merupakan PUFA (Poly Unsaturated Fatty Acid) golongan omega 6 (ChemSpider, 2015). Jenis asam lemak ini dibutuhkan oleh tubuh dalam pembentukan EPA (asam Eikosapentaenoat) (Djousse et al., 2001) dan dapat menurunkan kadar serum kolesterol dalam tubuh, sehingga dampak negatif dari sterol nabati dapat dinetralisasi (Andriani et al., 2014). Selain asam palmitat, asam linoleat, dan asam stearat, minyak tempe busuk sebelum dan sesudah pemurnian juga tersusun oleh komponen kimia lain dengan persentase yang lebih kecil yaitu sebesar $<3 \%$. Hasil penelitian ini berbeda dengan penelitian Keraba et al. (2017) yang melaporkan bahwa hasil pemurnian minyak tempe busuk pemeraman hari ketujuh hanya tersusun oleh tiga senyawa dan didominasi oleh metil oleat $(32,01 \%)$ 
diikuti oleh metil linoleat dan metil palmitat dengan persentase yang lebih kecil.

Pada minyak tempe busuk sebelum pemurnian, asam linoleat muncul sebagai puncak nomor 2 dengan nilai persentase area sebesar $77,57 \%$ dalam waktu retensi 21,456 menit. Sedangkan asam linoleat yang terkandung dalam minyak tempe busuk sesudah pemurnian muncul dalam dua puncak yang berbeda yaitu puncak nomor 2 dan puncak nomor 3. Nilai persentase area dari masing-masing puncak adalah sebesar $0,08 \%$ dan $80,27 \%$. Asam linoleat yang muncul dalam dua puncak yang berbeda tersebut diduga adalah isomer karena memilki rumus molekul yang sama akan tetapi hanya berbeda pada orientasi struktur ruangnya.

\section{SIMPULAN}

Hasil penelitian menunjukkan bahwa terdapat perbedaan jumlah asam lemak penyusun minyak tempe busuk hari kelima sebelum dan sesudah pemurnian yaitu minyak tempe busuk sebelum pemurnian mengandung delapan senyawa, sebaliknya minyak tempe busuk sesudah pemurnian hanya tersusun oleh lima senyawa. Delapan senyawa penyusun minyak tempe busuk sebelum pemurnian antara lain $n$ - Hexadecanoic acid / asam palmitat (13,33\%), 9, 12 Octadecadienoic acid (Z, Z)- / asam linoleat (77,57\%), Octadecanoic acid / asam stearat $(6,15 \%)$, dan lima komponen kimia lain yang memiliki persentase area $<3 \%$. Sebaliknya senyawa - senyawa penyusun minyak tempe busuk sesudah pemurnian terdiri dari $n$ Hexadecanoic acid / asam palmitat (12,38\%), 9, 12 - Octadecadienoic acid $(Z, Z)$ - / asam linoleat $(80,27 \%)$, Octadecanoic acid / asam stearat $(5,84 \%)$, dan senyawa lain yang jumlahnya $<3 \%$.

\section{DAFTAR PUSTAKA}

Albertina, H., Soetjipto, H., dan Andini, S. 2015. Pengaruh Lama Waktu Ekstraksi Minyak Biji Mangga (Mangifera indica L. Var Arumanis) Terhadap Sifat Fisiko Kimianya. Prosiding Seminar Nasional Kimia dan Pendidikan Kimia VII, "Penguatan Profesi Bidang Kimia dan Pendidikan Kimia Melalui Riset dan Evaluasi”. 18 April Universitas Sebelas Maret.
Andriani, M., Baskoro, K., dan Edhi, N. 2014. Studies on Physicochemical and Sensory Characteristics of Overripe Tempeh Flour as Food Seasoning. Academic Research International. 5(5): $36-45$.

ChemSpider. 2015. Methyl Linoleate. http: www.chemspider.com_Chemical-

Structure.4447491.html. 10 April 2018 (15.10).

Deliani. 2008. Pengaruh Lama Fermentasi Terhadap Kadar Protein, Lemak, Komposisi Asam Lemak dan Asam Fitat pada Pembuatan Tempe. Tesis. Medan : Program Studi Ilmu Kimia Sekolah Pascasarjana, Universitas Sumatera Utara.

Devi, A. F., Muzdalifah, D., Athaillah, Z. A., Artanti, N., and Udin, L. Z. 2017. Prosiding of the International Conference on Food Science and Nutrition.

Djousse, L., Pankow, J.S., and Eckfeldt, J.H. 2001. Relation Between Dietary Linolenic Acid and Coronary Artery Disease in the National Heart, Lung, and Blood Institute Family Heart Study. Am J Clin Nutr. 5 : $612-619$.

Gunawan, P., Wijaya, H., dan Mutukumira, A.N. 2012. The Utilization of Overripe Tempe (Tempe Semangit) as Indigenous Condiment. Prosiding $2^{\text {nd }}$ Workshop on Food Safety Technologies and Innovations Apllied to Food Safety.

Keraba, A.A., Soetjipto, H., dan Kristijanto, A. I. 2017. Isolasi dan Deteksi Komponen Kimia Hasil Pemurnian Minyak Tempe Busuk. Skripsi. Salatiga : Program Studi Kimia, Universitas Kristen Satya Wacana.

Ketaren, S. 1986. Pengantar Teknologi Minyak dan Lemak Pangan. Jakarta :UI - Press.

Rachmawati, M. H., Soetjipto, H., dan Kristijanto, I.A. 2018. Pengaruh Pemurnian Terhadap Profil Asam Lemak Minyak Tempe Busuk. Skripsi. Salatiga : Program Studi Kimia, Universitas Kristen Satya Wacana.

Setiawan, S.Y., Soetjipto, H., dan Kristijanto, I.A. 2017. Karakterisasi dan Identifikasi Komponen Kimiawi Minyak Tempe Selama Proses Pembusukan. Skripsi. Salatiga : Program Studi Kimia, Universitas Kristen Satya Wacana.

Triwibowo, R. 2011. Kajian Perubahan Biokimiawi Stakhiosa dan Asam Lemak Essensial Pada Tempe Kedelai (Glycine max) Selama Proses Fermentasi. Skripsi. Surakarta : Program Studi Teknologi Hasil Pertanian, Universitas Sebelas Maret. 
Profil Asam Lemak Minyak Tempe Busuk M. H. Rachmawati, H. Soetjipto, dan A. I G.N. Kristijanto

Verleyen, T., Sosinska, U., Ioannidou, S., Verhe, R., Dewettinck, K., Huyghebaert, A., and Greyt, W. 2002. Influence of the Vegetable oil Refining Process on Free and Esterified Sterols. Journal of the American Oil Chemists' Society. 79 : 947 $-953$. 